\title{
Prevention of inadvertent injury to the aberrant hepatic artery arising from SMA during laparoscopic pancreaticoduodenectomy
}

\author{
Mehmet Fatih $\operatorname{Can}^{1}$ (D), Mustafa Kerem²(D), Kürşat Dikmen²(D) \\ ${ }^{1}$ Lokman Hekim University, School of Medicine, General Surgery, Ankara, Turkey \\ ${ }^{2}$ Gazi University School of Medicine, General Surgery, Ankara, Turkey
}

\section{ABSTRACT}

Laparoscopic pancreatoduodenectomy is a challenging surgical procedure. Presence of aberrant hepatic artery arising from the superior mesenteric artery increases the complexity througout dissection. Herein we propose some important points and tricks that help surgeon avoid an inadverdent injury to aberrant hepatic artery during laparoscopic pancreatoduodenectomy.

Keywords: Pancreatoduodenectomy, laparoscopy, hepatic artery, injury

Cite this article as: Can MF, Kerem M, Dikmen K. Prevention of inadvertent injury to the aberrant hepatic artery arising from SMA during laparoscopic pancreaticoduodenectomy Turk J Surg 2020; 36 (3): 324-325

\section{Corresponding Author}

Mehmet Fatih Can

E-mail: mfcanmd@gmail.com

Received: 05.09.2017

Accepted: 02.01.2018

Available Online Date: 31.08 .2018

o Copyright 2020 by Turkish Surgical Society Available online at www.turkjsurg.com

DOI: 10.5152/turkjsurg.2018.3853
Dissection during laparoscopic pancreaticoduodenectomy (LPD) is a complex surgical intervention and requires a comprehensive understanding of anatomical relations and vascular variations around the duodenum and hepatoduodenal ligament. While the process carries a risk of inadvertent injury to the adjacent vasculature throughout the procedure, safe dissection along the superior mesenteric artery (SMA) is extremely vital since nearly one fifth of the patients have aberrant hepatic artery (HA) coming off of the superior mesenteric artery (1). If exists, the replaced or accessory hepatic artery typically courses just right and inferior to the portal vein. With accompanying video, this paper aims to share the technique we adopt to avoid injury to the aberrant hepatic artery during LPD.

We believe adherence to some technical rules will significantly reduce the risk of an accidental arterial injury during the procedure:

1. Preoperative radiological evaluation: Vascular anatomy and variations of the hepatic artery should be assessed preoperatively with high quality computed tomography imaging. Both arterial and portal phase images should be obtained. The three commonest variations of HA coming off of the SMA are accessory right $H A$, replaced right $H A$ and replaced common hepatic artery (Figure 1). It should

\section{Replaced right HA}

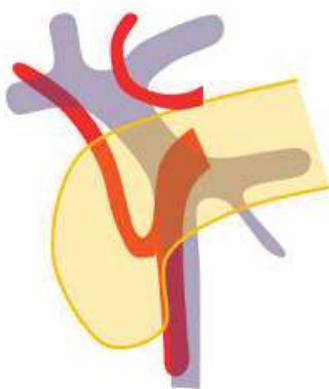

\section{Replaced common HA}

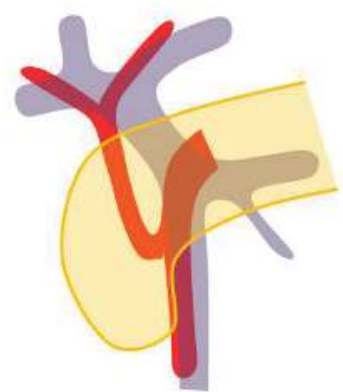

\section{Accessory right $\mathrm{HA}$}

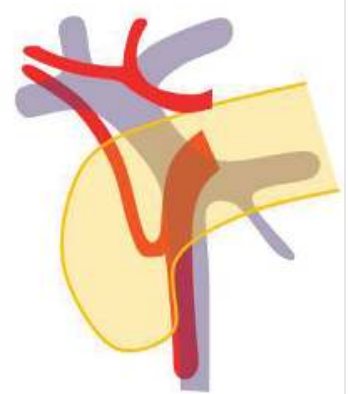

Figure 1. Three commonly encountered types of aberrant hepatic artery arising from the superior mesenteric artery. 
also be noted that the aberrant vessel may have a short or long course beneath the portal vein (PV).

2. The landmark \#1 to identify aberrant HA: The first jejunal branch of the superior mesenteric vein (SMV) is a reliable landmark to identify the area where SMA is encountered during the uncinate process dissection (Video). However, an aberrant HA often origins from a point closer to the root of SMA. Radiological assessment with MPR images aids in determining the level at which the aberrant artery comes off.

3. Traction and counter-traction: Adequate retraction with proper triangulation of the organs and tissues is of paramount importance during advanced laparoscopic surgery. However, over traction on portal vein may also cause axial displacement of the vein; which, in turn, can disrupt surgeon's orientation to the portal vein/aberrant HA relationship (Video: asterisk shows tip of the sealing device while dissecting on incorrect area). Anatomical vascular neighborhoods should be checked by releasing all retractors if suspicion arises.

4. The landmark \#2 to identify aberrant HA: It is easier to identify an aberrant HA during dissection of the hepatoduodenal ligament $(\mathrm{HDL})$ than when uncinate process is being dissected (video). The artery can be found just beneath the common bile duct (CBD) immediately after the gastroduodenal artery is ligated and divided. It is now our practice to complete HDL dissection and secure HA, PV, CBD and accessory/replaced HA (if any) by placing a tape around each. This should preferentially precede dissection over the inferior edge of the pancreas, infrapancreatic tunnel creation and uncinate process dissection.
Transection of the neck of the pancreas should not be delayed. Nevertheless, it is essential to know that earlier identification of an aberrant HA distally may not guarantee to prevention of the the artery during uncinate process dissection.

5. Nearby structures mistaken for aberrant HA: A thick lymphatic vessel or a long lymph node may be mistaken for an accessory or replaced HA, especially when the uncinate process dissection has fairly advanced (Video). Looking for arterial pulsation helps discriminate between an artery and a lymphatic vessel. Continuity of the structure should also be viewed before placement of a sealing device at this region.

\section{Ethics Committee Approval: Not Relevant.}

Peer-review: Externally peer-reviewed.

Author Contributions: Concept - M.F.C.; Design - K.D.; Supervision - M.K.; Resource - M.F.C., M.K., K.D.; Materials - M.K.; Data Collection and/or Processing - K.D.; Analysis and Interpretation - M.F.C.; Literature Review - M.K.; Writing Manuscript - M.F.C.; Critical Reviews - M.F.C., M.K.

Conflict of Interest: The authors have nothing to disclose.

Financial Disclosure: The authors declare that they received no financial support for this study.

\section{REFERENCE}

1. Dudeja V, Fong Y. The liver. In: Towsend CM, Beauchamp RD, Evers BM, Mattox K, editors. Sabiston textbook of surgery. 4 ed. Philedelphia: Elsevier; 2017. pp. 1425. [CrossRef]

\title{
CERRAHI TEKNIK-ÖZET
}

Turk J Surg 2020; 36 (3): 324-325

\section{Laparoskopik pankreatikoduodenektomi sırasında SMA kökenli aberran hepatik arter yaralanmasının önlenmesi}

\author{
Mehmet Fatih Can ${ }^{1}$, Mustafa Kerem² ${ }^{2}$ Kürşat Dikmen² \\ ${ }^{1}$ Lokman Hekim Üniversitesi Tıp Fakültesi, Genel Cerrahi Anabilim Dalı, Ankara, Türkiye \\ ${ }^{2}$ Gazi Üniversitesi Tıp Fakültesi, Genel Cerrahi Anabilim Dalı, Ankara, Türkiye
}

\section{ÖZET}

Laparoskopik pankreatoduodenektomi oldukça zorlu bir cerrahi işlemdir. Süperior mezenterik arter kaynaklı aberran hepatik arter varlığı diseksiyonu daha da kompleks hale getirmektedir. Bu yazıda, laparoskopik pankreatoduodenektomi ameliyatı sırasında cerrahın aberran hepatik arteri yaralamasını önlemeye yardımcı olacak bazı önemli nokta ve püf noktaları önerilmiştir.

Anahtar Kelimeler: Pankreatoduodenektomi, laparoskopi, hepatik arter, yaralanma

Doi: 10.5152/turkjsurg.2018.3853 